\title{
The Analysis of Occupational Health and Safety of The Ship's Crew on Board in The Enclosed Spaces
}

\author{
Nurwahidah \\ Politeknik Ilmu Pelayaran Makassar \\ JL Salodong No.1 Kel. Untia, Kec. Biringkanaya, Makassar. \\ nurwahidahpipmks@gmail.com
}

\begin{abstract}
The research on enclosed spaces is used to identify the work accidents, availability of the Occupational Health and Safety (OHS) equipment as well as the suitability of SOPs used by the Officer to handle the occupational accidents on board.The methodology used to identify the occupational accident in enclosed spaces were quantitative analysis based on some primary data (primary analysis) and secondary data (secondary analysis), by which the author performed the direct observations, interviewed the respondents who experience the accidents and did the literature study.The results confirmed that the enclosed spaces is not used for the activities or daily work by the ship's crew since the rooms have no ventilation, thus the air inhaled is less than $21 \%$ by volume and the concentration of hydrocarbon gas is less than $1 \%$ of the LFL (Limite Flamble Lower) than the levels of other toxic gases. Based on the interview results of 175 respondents, $93 \%$ said the accident was caused by the negligence of the supervision or personal responsibility, $21 \%$ said that it was caused by the absence of carbon gas test since there were no tools for detecting the toxic gas (gas detector) and $78 \%$ claimed that they understand that the occupational accidents happened in enclosed spaces due to the negligence and procedural error (SOP). Therefore, it can be said that the limitations of knowledge and understanding of the crew, granting permits (work permit) by Officers which was not appropriate, the availability of supporting equipment and the inadequate involvement of shipping companies, the SOP that are not well socialized and the improper handling of accident victims were the causes of the work accidents on board.
\end{abstract}

Keywords: OHS, SOP, Enclosed Spaces

\section{Introduction}

Since the ship is a mean of goods and humans transportation, it should meet the standards of safety which refers to the regulation of SOLAS (Safety of Life at Sea) 1974 consolidated edition 2014 and ensure occupational health for all the ship's crew [4]. The application of the occupational health and safety (OHS) regulation is expected to optimize the work or the activities on the board, that the crew can work under the safe, healthy, and comfortable condition. Occupational Health and Safety is the fundamental demand of workers since it is closely related to their well beings. [3]. Working in enclosed spaces put a risk to the health and safety of the seafarer on board since the spaces provide some sources of danger from chemicals containing toxic, and flammable substances (gas, steam, smoke, dust and others) and other physical risks arising such as noise, wet/slippery surfaces and the fall of a hard object resulting in the death of sailors in working on board.

This paper is presented in The $4^{\text {th }}$ International Conference on Maritime Education and Training October $8^{\text {th }}$, 2020, Makassar, Indonesia 
Working in a confined space certainly poses a risk to safety and health for sailors on board, considering that limited space contains several sources of danger from chemicals that contain toxins, and flammable substances. In addition there are other dangers in the form of oxygen deficiency or preferably excessive oxygen levels, extreme temperatures, trapped or engulfed (engulfment), as well as other physical risks that arise such as noise, wet / slippery surfaces and falling hard objects in the room. limited which resulted in work accidents resulting in the death of sailors who worked on the ship.

Table 1.1. Fakta Kecelakanan Kerja di Ruangan Tertutup

\begin{tabular}{|c|c|c|c|c|c|}
\hline No & Name of Ship & $\begin{array}{c}\text { Actual } \\
\text { Accident }\end{array}$ & $\begin{array}{c}\text { Date } \\
\text { Accident }\end{array}$ & $\begin{array}{l}\text { Location } \\
\text { Accident }\end{array}$ & Remaks \\
\hline 1. & MT Victoria 11 & 1 person & 14 Jan 2019 & Fuel tank & $\begin{array}{c}\text { Cleaning tank } \\
\text { ballast }\end{array}$ \\
\hline 2. & MT Paluh Tabuan & 2 persons & 30 Des 2019 & Fuel tank & $\begin{array}{l}\text { Cleaning tank } \\
\text { ballast }\end{array}$ \\
\hline 3. & TB Aditya 55 & 4 persons & $\begin{array}{c}19 \text { April } \\
2019\end{array}$ & Barge & $\begin{array}{c}\text { Check for Tank } \\
\text { Barge }\end{array}$ \\
\hline 4. & MT Nusantara Akbar & 1 persons & 14 Feb 2016 & $\begin{array}{l}\text { Fresh water } \\
\text { tank }\end{array}$ & Cleaning hatch \\
\hline 5. & TB Alpine Marine 12 & 3 persons & & $\begin{array}{l}\text { Fresh water } \\
\text { tank }\end{array}$ & $\begin{array}{l}\text { Cleaning Tank } \\
\text { Fresh water }\end{array}$ \\
\hline
\end{tabular}

Data Processing, 2020

The potential hazards can cause occupational accidents because the physical and chemical condition cannot be identified clearly in the enclosed spaces, while the standard operating procedures and the availability of facilities used in working were not appropriate. Based on the description of facts of occupational accident in enclosed spaces that the risks resulting in accidents and even loss of lives of the crew on board, the researcher formulated notions, (1) that causing the accident on the crew in an enclosed space in the fuel tanks and fresh water tanks, (2) actions in handling work accident have met the providing procedures, (3) Standard Operating Procedures, regarding entering an enclosed space have met the occupational health and safety criteria. The purpose of this study are to identify the problem on occupational accidents, availability of safety and medical equipment as well as the suitability of the SOP used for the prevention of occupational accidents by the Officers on board in enclosed spaces.

\section{Literature Review}

According to the OHSAS (Occupational Health and Safety Assessment Series) 18001, 1999. in Shariff, 2007. Occupational accident is a sudden incident which is not desirable resulting in death, injuries, property damage or loss of time. Work accident is an accident that occurs on someone related to working and most likely caused by the danger in relation to workers and working duration. Supporting the implementation of occupational health and safety by performing the procedure that requires the organization consistently identify and control risks to health and safety in the workplace as well as improve the performance and company image. Work in enclosed/confined spaces is risked by potential hazard. Thus it needs the application of Occupational Safety and Health (OHS) program to ensure the safety and health for seafarers on board. Confined Space, according to Ir. Amri AK, is the room that has the following characters, the room construction only sufficient for a person to enter and perform work in it, in and out access 
is limited and not designed as working space and to work continuously in it, because this room does not have continuous ventilation that the air in these spaces is harmful to the human due to the presence of hydrocarbon gas, toxic gas, as well as the lack of oxygen levels in it [2]. The procedure of entering an enclosed room is testing the quality of the atmosphere, by making sure the necessary oxygen level required is $21 \%$, and ventilation equipment operates correctly. Have standard operating procedures and the availability of adequate infrastructure on the ship.

\section{Research Method}

Based on the formulation of the problem then the researcher used the quantitative research by using the primary data collection methods, direct observations of on board condition by witnessing the enclosed space on the ship, the process of entering an enclosed spaces based on the SOP, interviews 175 crews that have sailing experience, the vessel's situation and condition. Then secondary analysis was used by taking some of the ship's documents on board that was the SOP of entering the enclosed spaces, the checklist entering the enclosed space, documentation of entering the enclosed space/the readiness of equipments of entering the enclosed space, licensing documents of entering the enclosed space, the checklist safety equipment. From 175 respondents, the researcher selected 25 respondents and then 5 respondents to explore and get more in-depth interview results.

Table 1.2. The List of Questions

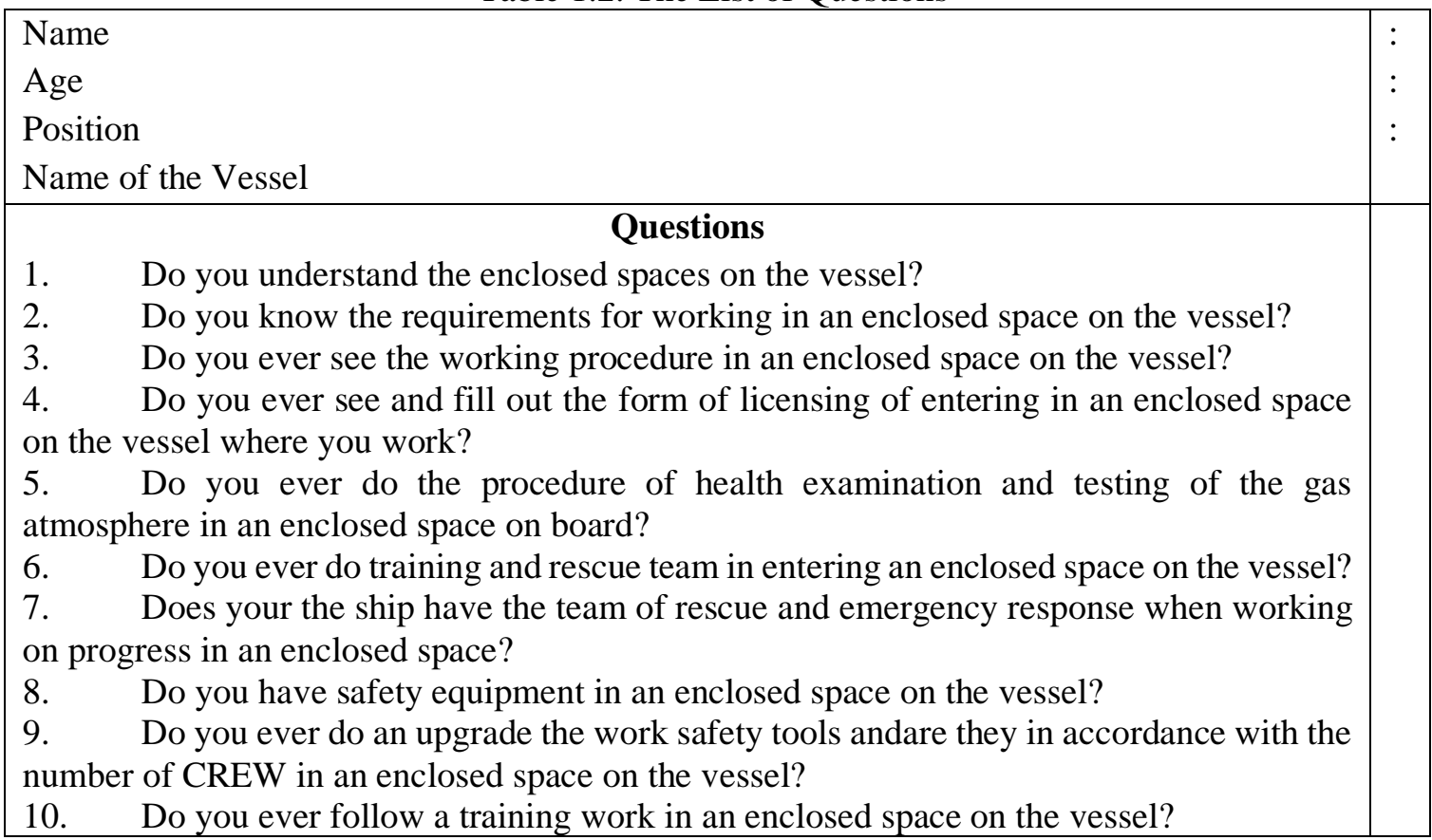
Processed Data, 2020.

3.1.The data obtained then analyzed by the descriptive statistics that serve to describe the object to be examined through the sample or population data as is, without doing analysis and making general conclusions. Activity in an enclosed space already caused many deaths due to those conditions. An enclosed space on the ship such as, cargo spaces, double bottoms, fuel tanks, ballast tanks, cargo pump-rooms, cargo compressor rooms, cofferdams, chain lockers, void spaces, duct keels, inter-barrier spaces, boilers, engine crankcases, engine scavenge air receivers, sewage tanks, and the room next to or connected with the enclosed space mentioned. Some of the things

This paper is presented in The $4^{\text {th }}$ International Conference on Maritime Education and Training 226 
that must be considered to enter the enclosed space for the security and safety on board, as follows:

3.1.1. All door or hatch cover in the enclosed space should be close if it is not required or do other activities for the entering of a person or crew into it.

3.1.2. If an enclosed room is entered or doing work activities, then all the doors or hatch cover should be in open as a vent and must be in the guard or in pairs barrier in order to remain open.

3.1.3. All the supplies will be used in an enclosed space should be in good working condition and be checked before the room is used.

Every crew who will enter the enclosed room has to get permission to enter the room (permit work) from the Capten or the Officer or the responsible person in the form of entry permit and has implemented security procedures on board. The Capten and the Officer or the responsible person in determining that an enclosed room is safe to enter should consider several things, namely :

3.2.1. Potential accidents or hazards have been identified in the assessment and declared safe

3.2.2. The room ventilation should be adequate to remove toxic or flammable gases and to ensure levels of Oxygen in the enclosed room is sufficient for the number of crews that will enter the room.

3.2.3. The atmosphere of the room should be undergone the testing in advance with the tools that have been calibrated to ensure the oxygen level and the combustible gas level or toxins can be accepted or inhaled by the crew at the time of work activities in an enclosed room.

3.2.4. The enclosed room must be secured for the entry of a person or the crew and has been equipped with the lighting.

3.2.5. All parties concerned should use the tools of communication according to the provisions and distance covered by the tools of such communication.

3.2.6. An attendant is instructed to stand guard at the entrance to the room closed as long as there are people or crew that entered it.

3.2.7. Rescue and resuscitation equipment(First aid box to resuscitate the victim who suffered injuries) have been positioned near the entrance in the standby condition for use and rescue arrangement has been approved.

3.2.8. Safety equipment and appropriate work uniform of the crew as well as the appropriate safety equipment has been used for related work in an enclosed room.

3.2.9. Having and approving the permit that has been given to the crew in the form of entry permit that has been acknowledged and signed by the person in charge (Officer on board).

In entering the enclosed space, the Officer responsible must make sure the oxygen levels are not passed by $21 \%$ by volume and the concentration of hydrocarbon gas is not more than $1 \%$ of the LFL (Limite Flamble Lower) than the levels of other toxic gases. Life lines and harnesses that exist around the tank and is ready for use, while the breathing apparatus and a respirator equipment should be ready for use. The use of the tools of test atmosphere should be approved by the classification society and must be preserved, then calibrated with the standards specified, (for Example N2 to the calibration of the $\mathrm{O} 2$ Analyzer and Butane 50\% for the calibration of Combustible Detector). The results of the maintenance, as well as the results of the calibration, should be recorded in a certain period, the one doing the calibration should be the people who are trained and have the ability to 
use such tools. The concentration of gas allowable are the hydrocarbons gas $1 \%<$ LFC $\%$, Benzene gas, Hydrogen Sulphine and other toxic gases, Oxygen $21 \%$ by volume.

3.2. On July 20, 2020, the researcher and the team conducting the initial data collection through interviews on the crew who still work on the ship and on the crew that have the leave and continuing their education. Researchers identify 175 respondents that being the sample in this study.

Table 4.1. List of the Respondent in the Interview

\begin{tabular}{|c|c|c|c|c|}
\hline $\mathrm{NO}$ & NAME & VESSEL & $\begin{array}{c}\text { PHONE } \\
\text { NUMBER }\end{array}$ & NOTES: \\
\hline 1 & Andi Fauzan Ichdar & MV Andhika Kanishka & 081355708715 & Have \\
\hline 2 & Rinno Reeflito M & KM Caraka Jaya III & 081272504496 & Have \\
\hline 3 & Muhammad Ridwan & MV CTP Bravo & 085386358368 & Have \\
\hline 4 & La Ulu & TB Buana Harbour 3210 & 081251416098 & Have \\
\hline 5 & Iskandar Joni & KM Hellespont Daring & 081294368913 & Have \\
\hline 6 & Yanmar & MT Harmoni Selatan & 085393910939 & Experience \\
\hline 7 & Saul M.P & TB Bluefin 6 & & Have \\
\hline 8 & Surya Angghi Saputra & AHTS Over Corner & 082153605834 & Experience \\
\hline 9 & Yohanes Makkayu & TB KSA 53 & 082153605834 & See \\
\hline 10 & M Kamrang & MV Marina 32 & & Have \\
\hline 11 & Muhammad Irfan & SPOB Jambo V & 081244794933 & Experience \\
\hline 12 & Zainal Abidin & SPOB King Ocean & & Have \\
\hline 13 & Zaifullah & KM Budi Mulia 68 & & No \\
\hline 14 & Awaluddin & TB Prime 4 & 085250966287 & Have \\
\hline 15 & Kadirman & KM Express Bahari 98 & 08114875314 & No \\
\hline 16 & Nasrul & MV Ena Jade & 085299209238 & No \\
\hline 17 & Herianto & MV Linton 159 & 082352417231 & No \\
\hline 18 & Robin Palipadang & TB Farel 15 & 085295713327 & Have \\
\hline 19 & Rudy Akbar & MV AOS Energy & & Have \\
\hline 20 & Sudarmin Baso & TB Masada27 & 08599197121 & No \\
\hline 21 & Ahmad Kadir & SPOB Ocean Mamuju & 082188865331 & Have \\
\hline 22 & Supardi N & TB Capitol T2002 & 081342457576 & Have \\
\hline 23 & Nopian Lando & TB Marina 12 & 085298451603 & No \\
\hline 24 & Rizaldi Razak & TB Marina 20 & 081356251712 & No \\
\hline 25 & & MV Masada 25 & 085240261304 & No \\
\hline
\end{tabular}

From 175 respondents interviewed, researchers only take as many as 25 people who became the sample to ease the deep identification on in-depth interviews to get maximum results. From all the sample selected, there are 5 respondents that the researchers defined as the resource used in the technique of sampling according to Margono (2004), that is a way to determine the number of sample based on the size of the sample that will be used as the source of actual data, regarding the behaviour and the spread of the population in order to obtain a representative sample [5]. 
Table 4.2. The List of Questions in the Interview

\begin{tabular}{|c|l|c|}
\hline NO & \multicolumn{1}{|c|}{ QUESTIONS. } & \multicolumn{1}{|c|}{ NOTES: } \\
\hline 1 & $\begin{array}{l}\text { Have you ever experienced or saw the accident on the ship } \\
\text { regarding performing work on an enclosed space? } \\
\text { Do you understand that accidents in enclosed spaces on the ship } \\
\text { due to the negligence of the crew and procedural error? } \\
\text { In carrying out work in an enclosed space, do you implement } \\
\text { the procedures in advance (for example testing the carbon gas } \\
\text { in the tank)? } \\
4\end{array}$ & $\begin{array}{l}\text { The all the death of the CREW on board in an enclosed space } \\
\text { (fuel tank and tank fresh water) due to the negligence of } \\
\text { Table } 4.2\end{array}$ \\
5 & $\begin{array}{l}\text { supervision? } \\
\text { If the procedure in entering the enclosed room has been filled } \\
\text { correctly, why is there still the death of the CREW on board? }\end{array}$ & \\
\hline
\end{tabular}

Processed data, 2020

Based on the results of the interview on the 175 crews with the 5 material questions that researchers conlude from the indicators of the problem. Regarding the first question (1), $90 \%$ of respondents said that the work activities in the enclosed room were never performed on the ship. Then $10 \%$ of them stated that they never did such activities. For the second question (2), 78\% of respondents said they understand that accident in enclosed spaces was due to the negligence and procedural error of the crew, while $15 \%$ of respondents said it was the negligence and only $7 \%$ of respondents said that it was due to the procedural error in the working process. For the third question (3), 67\% of respondents stated that the testing of carbon gas in the tank before carrying out the works in an enclosed room have been implemented according to the procedure, $21 \%$ of respondents said that they do not do testing of carbon gas because there is no toxic gas detector and only $11 \%$ of respondents said that they did not understand about the procedure. Regarding the fourth question (4), 93\% of respondents said the death of the crew in an enclosed room (for example fuel tank/freshwater tank/ballast tank) due to negligence in the supervision of the Officer or the Responsible Personal, and only $7 \%$ of respondents said the death because of the destiny of God. For the fifth question (5), 57\% of the respondents said the procedure of entering a closed room have been exercised correctly and follow the safety standards, but if there is still a death occurs in the room due to inhalation of toxic gas, $8 \%$ of respondents said that the death caused by fatigue of the crew and around $35 \%$ of respondents said that the death of the crew caused by the unfamiliarity on working procedure of entering a closed room on the vessel.

The researcher then collect more data through in-depth interview on five respondents who have experience personally and have seen the occupational accidents in the enclosed room above the ship, as follows :

Table 4.3. List of Respondents Who Experienced and Have Seen the Occupational Accident in the Enclosed Spaces.

\begin{tabular}{|c|l|l|c|l|}
\hline NO & THE NAME OF THE & VESSEL NAME \& TYPE & POSITION & NOTES: \\
& RESPONDENT & & & \\
\hline 1 & Joni Iskandar & MT Harmoni Selatan (Tanker) & C-Eng & Experience \\
2 & Surya Anggi Saputra & TB KSA 53 (Tug Boat) & C-Eng & See \\
3 & M Kamrang & SPOB Jambo V (Barge) & Master & See \\
4 & Saul M.P & AHTS Over Corner (Supply) & Master & Experience \\
5 & Andi Fauzan Y & MT ANDHIKA KANISHKA & C-OFF & See \\
& & (Container) & & \\
\hline
\end{tabular}

Processed Data, 2020. 
The first respondent interviewed by the researchers on 20 July 2020 at 4 p.m were the crews that have experience the occupational accident in an enclosed room, as follows:

3.3.1. Mr Joni, Iskandar as a Chief engineer or person in Charge in the Engine Department, this interview was conducted on 20 July 2020, at 10:30 LT on MT Harmony South Vessel of PT Sinyun Karya Abadi (SKA). The MT Harmony South vessel is a tanker that loads the oil in the category of malicious payloads. In the quote of interview result between researchers and respondents, he said, "I have an occupational accident on board when vessel travelled from Gresik Port to Sorong Port, at the time when the tank cleaning was undergone in the enclosed room, the accident was caused by the negligence in the supervision of the Officer or Person in Charge (the responsible person) of the crew who do not follow safety standards and procedural error in entering the room." The negligence of Officers and crew in the form of the absence to fulfil the check list before entering a closed room and the lack of tools availability to measure the gas atmosphere in the container tank.

3.3.2. Mr. Surya Anggi Saputra as the Head of the Engine Room on board. TBA KSA 53 vessel owned by PT Kartika Samudra Adijaya (KSA) is the tug that does the towing (hold and drive) a barge, he said, "I have seen the occupational accidents on the ship where I worked that time, where the crew got orders from the Officers to perform checks on the ballast tank of the barge (the Barge) that was leaking with the $2^{\circ}$ tilt angle and to ensure the presence of the leak then an enclosed room (enclosed spaces) or ballast tank checks was performed. The Helmsman at the moment who was still lacking sailing experience and had less understanding about the procedure of work in an enclosed room onboard, directly open the main hold (holes for people entering the spaces) and enter the tank without following the standard of operational safety. The helmsman died due to gas poisoning - he inhaled the toxic gases which exceeded the threshold of tolerance for $21 \%$ by volume and carbon gas exceeds $1 \%$. Based on the death of the crew in the official report of the incident, the Captain and Officers as the person in charge did not have any clear SOP as the guideline to perform work in an enclosed room and did not have the safety instrument (gas detector, safety shoes, helmet, etc.).

3.3.3. Based on observation and interview, the researcher identified that the occupational accident and the death of the crew in an enclosed room are caused by the situation that the activities carried out in an enclosed room is an emergency situation that should get fast corrective action in solving the worst and dangerous conditions onboard. However, regarding the activity in an enclosed room, which will be performed on the ship, the Officers and crew still have some limitations as follows :

a. Permits for entering an enclosed room is not yet fully understood by the Officers or the responsibility officer because of the level of competence which reflects the knowledge and understanding

b. The limited equipments that will be used by the crew in working in an enclosed space were greatly determined by the Shipping Company.

c. SOP (standard operating procedure) in entering an enclosed room which is owned by each ship was not disseminated properly to the crew and the Shipping Company had no concern for these conditions.

d. The involvement of the crew in working in an enclosed space which resulted in the accident as well as loss of the lives of the crew consists of a variety of factors, namely the supervision of Officers in performing the activities in an enclosed room is not done and can be said negligent (Permit work was not signed and the equipment was not appropriate). Knowledge about the toxic gases and the limits of tolerance to be inhaled in an enclosed room was not fully understood by the crew. Regarding the case of the death, which happened in an enclosed room onboard was happened to the crew that had sailing 
duration or working duration onboard (sailing experience) less than 5 years, and this death frequently happened due to incompetence of the crew.

e. The countermeasures when an accident occurs in a closed room onboard did not perform in accordance with the OHS (Occupational Health and Safety) especially when the crew was injured, e.g. broken bone, fall from a height and the inhalation of toxic gases.

\section{Acknowledgement}

There were many obstacles or challenge that the research team faced in collecting the data, as well as at the stage of processing data. However, by the help of various parties, this research report can be compeleted in timely manner. In this occasion, the research team would like to express highest appreciation to the Director of Politeknik Ilmu Pelayaran (PIP) Makassar, Capt. Sukirno, M.M.Tr.,M.Mar. , Head of Research Center Dr. Rukmini, ST.,MT. and the all crews who have become a respondent as well as the entire team of researchers who have contributed significantly in the completion of this research report.

\section{Conclusion}

An enclosed room which is the room on the ship which is not recommended for crew to do any daily activities or work, except on certain urgent conditions that need to be handled immediately. Based on the discussion and analysis result, the researcher can conclude the problem as follows;

1. Occupational accidents and the death of the crew that occur in an enclosed space in the vessel's tanks were caused by many factors, i.e. knowledge and the ability in understanding the dangers of working in an enclosed room, as well as operating procedures for work that is not disseminated appropriately by the Officer (responsibility personal) at the time of sign on and the absence of support from the shipping companies in meeting the safety equipment that will be used according to safety standard.

2. The measures in the handling of occupational accidents at work in an enclosed room have not been implemented according to the standard operating procedures, providing that there were still many accidents that occur onboard.

3. The Occupational Health and Safety (OHS) measure in entering the enclosed spaces has not meet the criteria yet.

\section{Suggestions}

1. The Captain and Officers as a responsibility person onboard are responsible in disseminating an enclosed room in detail (hazards posed) in regular basis and when having the crew's rotation.

2. The shipping company should provide support to the crew in providing the equipment as the provision to work in an enclosed room.

3. The crew must meet the conditions set forth in the SOP on the vessel.

\section{References}

[1] Direktorat Pengawasan Norma Keselamatan Kesehatan Kerja. Pedoman K3 di Ruangan Terbatas (confined spaces), September 2006.

[2] Ir. Amri AK, Pengetahuan Umum Tentang Ruangan Tertutup (confined spaces), 2016.

[3] Sucipto, CD, Keselamatan dan Keselamatan Kerja.Yogyakarta : Goeyen Publishing : 2014.

[4] SOLAS 1974 Consolidated Edition, 2014.

[5] Margono 2004. Metodologi Penelitian Pendidikan, Jakarta.PT Rineka cipta. 